\title{
Sustainability Checklist for Transport System Plan for Mangrove Eco-Park
}

\author{
Moch Zamani Achmad ${ }^{1}$, Syed Ahmad Iskandar Syeed Arifin ${ }^{2}$, Ahmad Faizal Ahmad Fuad ${ }^{3}$, Asmawi Abdul \\ Malik $^{4}$, Ismail Zainol ${ }^{5}$
}

\begin{abstract}
Preservation of mangrove, like efforts on preservation of other natural ecosystem, is directly connected to sustainability. Eco-park as one model of mangrove eco-tourism is well accepted worldwide. Mangrove eco-park comprises of accommodations, edutainment centre, galleries, restaurants, etc. If these facilities are not properly planned and sustainability elements are not incorporated they will have negative effects to the preservation effort. The incorporation of sustainability elements in planning is already a standard practice by many district councils in developed countries like US and UK. Developers are to conform to the sustainability checklists failing which their project many not be approved. To be able to accommodate all type of development proposal the checklists are generic. Conformation to sustainability is required overall rather than the project systems and sub-systems. Therefore the checklists can be used for control purposes but with great limitations. System specific sustainability is required. This study identifies the generic model of a typical mangrove eco-park systems, sub and sub-sub systems and proposed their individual primary sustainability elements. A simplified model has been applied to the planning of transport system for Tanjong Pelepas Eco-Park (TPEP), a mangrove preservation effort by a Malaysian Port Authority. Thirty three eco-park sub-sub-systems have been prioritised and their primary sustainability elements identified. Parties responsible for the sustainability elements, either designer or TPEP operator, or both have been identified. The checklist is expandable and could be used to develop TPEP's standard operating procedures.
\end{abstract}

Keywords—-sustainability checklist, transport system, mangrove eco-park.

\section{INTRODUCTION}

$\mathrm{T}$ ransport system plan is the product of translating an area development masterplan that lays out locations of activity centres for the whole area into a dynamic system of logistic and transportation. A transport system connects the activity centres such that, as elements of an input-process-output system, the centres can function efficiently and in support the visions, missions and objectives of the regional development. Mangrove ecoparks, which is originally wetland area covered by tidal flooding and consisting of three zones [1] [2]: (a) mudflats in the zone below mean sea level; (b) mangrove forests in the zone between mean sea level and the level of higher neap tides; and (c) salt flats in the zone above the level of higher neap tides, are eco-tourist attraction and hence they are developed to generate income [3] a portion of which is normally channelled as fund for the preservation of the ecosystem. Mangrove eco-parks offer varieties of recreational facilities depending on it nature and size. As such the transport system plan for a mangrove eco-park itemises the system's hardware and software components for the prime objectives of providing efficient and safe transportation services to eco-park visitors and operators. One of its most important missions is, surely, visitors' satisfaction and the vision could be preservation of the Earth.

Eco-parks' operational goals should be optimising use

Author name is with Departement of ..... University/Institution, City, Postal Code, Country. E-mail:....................

Author name is with Departement of ..... University/Institution, City, Postal Code, Country. E-mail....................

Author name is with Departement of ...., University/Institution, City, Postal Code, Country. E-mail:.................. of resources, maximising profit, maximising social contribution and minimising threats to the environment and these are jointly shouldered by its unit managing the transport system. These goals are in fact the pillars of sustainability which are only achievable if the eco-park project is holistically and thoroughly manage at all levels and all stages. More so it is at planning stage where system and sub-systems are identified to give character and functionality to the eco-park. Short sightedness in managing system sustainability encompassing the whole issue of identifying, incorporating into project plans and project documents, incorporating into system designs, monitoring during implementation stage and incorporating into standard operating procedures will result in failure of the system's sustainability

The use of sustainability checklists at planning stage is quite common especially in developed countries. However, it is evidence that the content is more on what is required by city council's planners who are not practically involved in monitoring the implementation of any particular project and later its day-to-day operation.

The checklists adopt the yes/no format and when filled up become a record of non-quantifiable claim on the part of the developer based on a standard list of sustainability elements applicable to all possible projects under the jurisdiction of the councils. The standard list captures as much possible elements as possible that, when applied, finally ends up with lack of real results.

\section{LITERATURE REVIEW}

MohdZamani et. al (2015) shared both the conventional design framework and design process for engineering system and revised them to be sustainabilitybased [4]. The revised framework shows that sustainability guidelines influence the system and its design not on selected elements but overall and encompassing. The points of contact of sustainability 
elements with the elements in the design framework and design process are quite infinite. His recommendation are (i) design practices should be revised and format for the presentation of design's reference documents such as standards, rules and guidelines, engineering and technical specifications must be improved such that sustainability criteria are well defined using meaningful expression, formulas and values, (ii). extra effort and resources are required to execute the additional task of identifying relevant sustainability criteria affecting their design, scanning sustainability oriented engineering and technical specifications, selecting the most appropriate sustainability-friendly equipment and facilities and putting emphasis on conservation of energy, pollution prevention, waste reduction and material management throughout the project's lifecycle must be rewarded, and (iii). the equations used for techno-economic viability should also be accordingly revised so as to appreciate the benefits of sustainability to an engineering project. The has been adopted by Nur Hanani et. al in developing the standard specifications for design concepts of mega floats for long term habitation [4].

Sustainability checklist of Welwyn Hatfield District Plan captures factors that should be addressed in making development sustainable [5]. They are categorised into three sections a) the citing of the proposal and the existing land use; b) the impact and use of the development once it is built and; c) the operation of the site during the construction period. The intention is for all applicants to demonstrate that their development is consistent with the principles of sustainable development by submitting a statement with their application assessing the proposals against a checklist of sustainability criteria. It is to be noted that the checklist is quite separate from statement to be submitted on urban design that shows how a development plan satisfies the design principles and standards. Welwyn Hatfield District Plan admits that not all the criteria are applicable to all forms of development. Larger scale development is expected to address most of the criteria within their statement while smaller scale development may address only some. Section A checks on avoidance of loss of urban space, maximising development lifespan, avoidance of sensitive areas. Section $B$ asks on minimisation of pollution, management of water resources, energy efficiency, waste management, preservation of habitats and species, interest of local community, accessibility, safety and health and economic contribution when fully built while Section C checks the same during construction period.

Major concern of Lewes District Council on sustainability is on 8 categories [6]; (i) preservation of natural features and habitats from, say, flooding, (ii) reduction and waste of energy, (iii) recycling of waste, (iv) suitability of housing in term of affordability, green, future adaptability (v) economic activity for local community including employment, business start-ups and training (vi) protection of land, air and water against pollution and mitigation measures, (vii) sustainable transport through the promotion of car clubs, green travel plan and cycle facilities, and (viii) crime protection. Applicants are guided by descriptions for each item in the 8 categories of concern when either it is "fully met", "partially met" or "not met". For example, the description for a fully met sustainable transport (category 7 ) is "A wide range of sustainable transport measures has been included in the development and a travel plan has been developed." The comment by the applicant to specify the wide range of sustainable transport measures and the many travel plans proposed for users.

Dorset District Council via its Strategic Partnership includes in their Regional Sustainable Development Framework sustainability requirements encompassing [7] (i) development of sustainability learning and skill for local community, (ii) encourage healthy lifestyles, (iii) improve equality in meeting basic needs, (iv) concerns on the environment, (v) support low carbon economic initiatives, (vi) encourage fuel efficiency and low carbon travel, (vii) maximise use of local goods and services, (viii) support public and community decision making, and (ix) take account of climate change.

\section{TRANSPORTATION SYSTEM MODEL FOR TANJONG PELEPAS MANGROVE ECO-PARK}

Tanjong Pelepas Mangrove Eco-Park is a USD15 million project undertaken by the Johor Port Authority of Malaysia to salvage $2 \mathrm{~km}$ stretch of mangrove land likely to be impacted by the Forest City project nearby which builds 4 man-made islands that has been confirmed to affect the water current around it. The project masterplan has been laid out such that the transportation system required shall principally cover (i) the function of ferrying visitors and crews from land to its main gate where they park their vehicles to the central reception area, (ii) walkways from the central reception area to the respective recreational centres and mangrove viewing walkways, (iii) logistic requirement to handle cargo of materials and equipment for merchandising related activities, and (iv) transportation system for search and rescue operations. The transportation system requires tunnel and bridges landward as well as jetties seaward. The project is jointly owned by Johor Port Authority and Port of Tanjong Pelepas Sendirian Berhad. Upon completion the mangrove eco-park will be operated by a nominated contractor.

Figure 1 shows a simplified model showing elements of the physical transport system for a typical Tanjong Pelepas Mangrove Eco-Park. The system is made up of two primary sub-system; land transport and sea transport. The sub-systems are further subdivided into sub-sub systems. Consistency has been maintained in identifying and recording the sub-sub system such that they are all physical elements of the transportation system. Subdividing has also been based on the traceability approach proposed by MohdZamani et al. (2015) and NurHanani et al. (2015). Figure 2.1 to 2.3 show each of the physical elements making up the mangrove eco-park transportation system and propose the respective primary sustainability elements. These sustainability elements are then assigned to designers if the physical elements are not of off-the-shelves types and have to be designed before construction on site. Sustainability elements for physical items readily available off-the-shelves are assigned to operators who will later purchase the items direct. Designers are responsible to design sustainability- 
efficient systems while operators are responsible in selecting equipment with sustainability-efficient technical specifications and operating them in a sustainable-efficient ways proposed by the manufacturers.

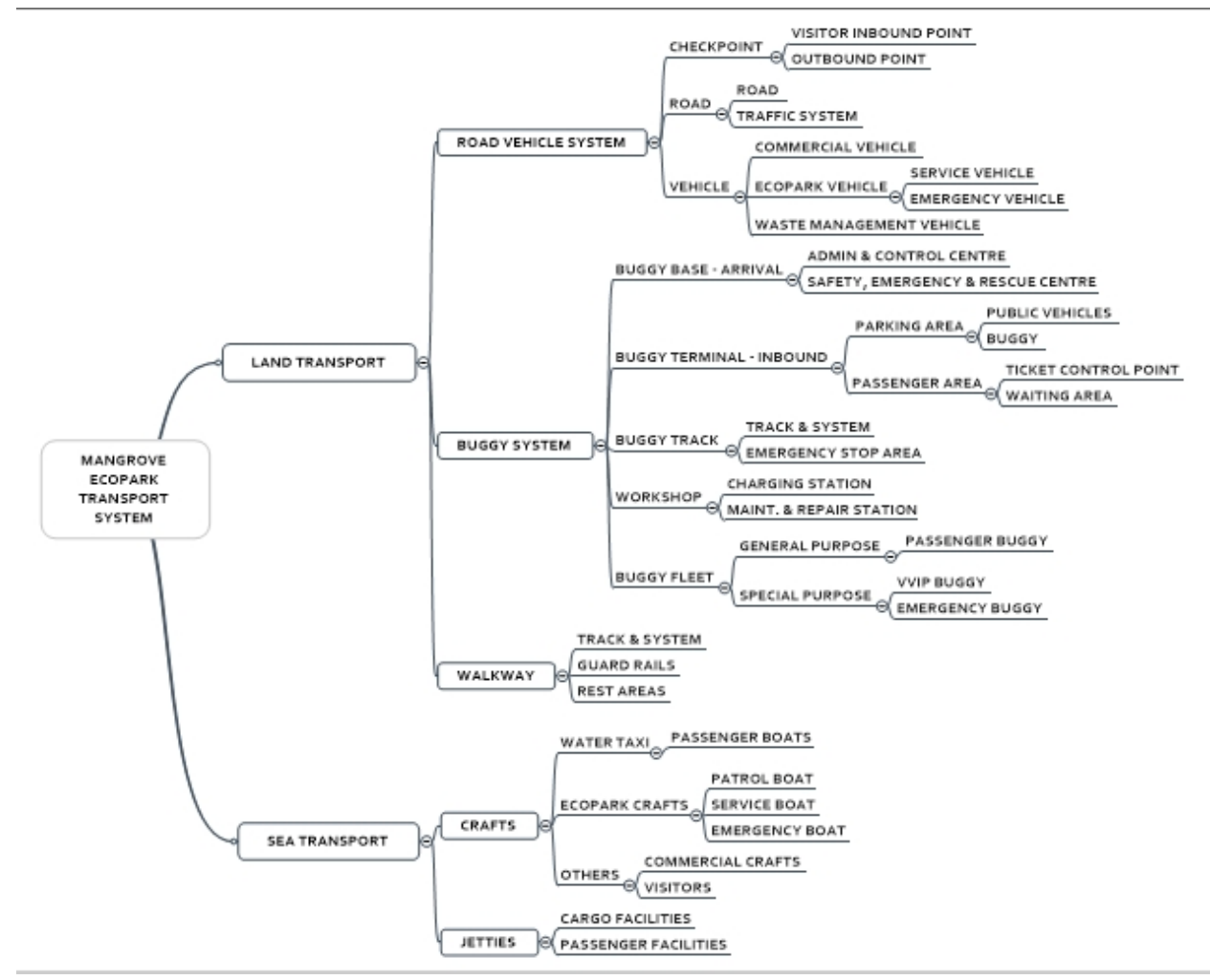

Figure. 1. Transportation system model for a typical mangrove eco-park.

TABLE 1 .

SUSTAINABILITY ELEMENTS FOR ROAD VEHICLE AND FOOTPATH SYSTEMS

\begin{tabular}{|c|c|c|c|c|c|c|}
\hline Category & System & sub-system & sub-sub system & sub-sub-sub system & Sustainability Element (Eg) & Party in Charge \\
\hline \multirow{10}{*}{$\begin{array}{l}\text { Land } \\
\text { Support }\end{array}$} & \multirow{8}{*}{$\begin{array}{l}\text { Road } \\
\text { Vehicle } \\
\text { System }\end{array}$} & \multirow[t]{2}{*}{ Road } & Road Track & & $\begin{array}{l}\text { Green \& recycled } \\
\text { construction materials energy } \\
\text { efficient machineries, lw } \\
\text { carbon emmisions } \\
\text { machineries }\end{array}$ & Designer \\
\hline & & & Traffic System & & $\begin{array}{l}\text { Renewable Energy } \\
\text { system,Energy saving ssytem }\end{array}$ & Designer \\
\hline & & \multirow{4}{*}{ Vehicle } & \multirow{2}{*}{ TPEP system } & Service Vehicle & Low Carbon emission & Operator \\
\hline & & & & Emergency Vehicle & Low Carbon emission & Operator \\
\hline & & & Commercial Vehicle & & Low Carbon emission & Operator \\
\hline & & & Municipal Vehicle & & Low Carbon emission & Operator \\
\hline & & \multirow{2}{*}{ Checkpoint } & $\begin{array}{l}\text { Inbound Checkpoint } \\
\text { \& System }\end{array}$ & & $\begin{array}{l}\text { Green \& recycled } \\
\text { construction materials energy } \\
\text { saving system }\end{array}$ & Designer,Operator \\
\hline & & & $\begin{array}{l}\text { Outbound checkpoint } \\
\text { and system }\end{array}$ & & $\begin{array}{l}\text { Green \& recycled } \\
\text { construction materials energy } \\
\text { saving system }\end{array}$ & Designer,Operator \\
\hline & \multirow{2}{*}{ Footpath } & $\begin{array}{l}\text { Covered } \\
\text { Walkaways } \\
\text { and systems }\end{array}$ & & & $\begin{array}{l}\text { Green \& recycled } \\
\text { construction materials energy } \\
\text { efficient machineries, lw } \\
\text { carbon emmisions } \\
\text { machineries }\end{array}$ & Designer \\
\hline & & $\begin{array}{l}\text { Rest Area } \\
\text { and systems }\end{array}$ & & & $\begin{array}{l}\text { Green \& recycled } \\
\text { construction materials energy } \\
\text { efficient machineries, lw } \\
\text { carbon emmisions } \\
\text { machineries }\end{array}$ & Designer \\
\hline
\end{tabular}


TABLE 2.

SUSTAINABILITY ELEMENTS FOR BUGGY SYSTEM

\begin{tabular}{|c|c|c|c|c|c|c|}
\hline Category & System & sub-system & sub-sub system & sub-sub-sub system & Sustainability Element (Eg) & Party in Charge \\
\hline $\begin{array}{l}\text { Land } \\
\text { Transport }\end{array}$ & $\begin{array}{l}\text { Buggy } \\
\text { System } \\
\end{array}$ & $\begin{array}{l}\text { Buggy base } \\
\text { Arrival Point }\end{array}$ & Admin \& Control Centre & & $\begin{array}{l}\text { Green materials, paperless } \\
\text { operations }\end{array}$ & Designer,Operator \\
\hline \multirow{12}{*}{$\begin{array}{l}\text { Land } \\
\text { Transport }\end{array}$} & \multirow{12}{*}{$\begin{array}{l}\text { Buggy } \\
\text { System }\end{array}$} & $\begin{array}{l}\text { Buggy base } \\
\text { Arrival Point }\end{array}$ & Emergency Centre & & $\begin{array}{l}\text { Energy saving System, efficient } \\
\text { energy usage }\end{array}$ & Designer,Operator \\
\hline & & $\begin{array}{l}\text { Terminal } \\
\text { Inbound }\end{array}$ & Parking Area \& System & Visitors parking & $\begin{array}{l}\text { Green \& Recycled constructionn } \\
\text { materials,energy saving system }\end{array}$ & Designer,Operator \\
\hline & & \multirow{4}{*}{$\begin{array}{l}\text { Buggy } \\
\text { Terminal } \\
\text { Inbound } \\
\text { Buggy Track }\end{array}$} & \multirow{2}{*}{$\begin{array}{l}\text { Parking Area \& System } \\
\text { Passenger Area \& } \\
\text { System }\end{array}$} & Buggy parking & $\begin{array}{l}\text { Green \& Recycled constructionn } \\
\text { materials,energy saving system }\end{array}$ & Designer,Operator \\
\hline & & & & Ticket Control & $\begin{array}{l}\text { Green materials, efficient energy } \\
\text { usage }\end{array}$ & Designer,Operator \\
\hline & & & \multirow{2}{*}{$\begin{array}{l}\text { Passenger Area \& } \\
\text { System } \\
\text { Main Track \& System }\end{array}$} & Waiting area & $\begin{array}{l}\text { Green materials, efficient energy } \\
\text { usage }\end{array}$ & Designer,Operator \\
\hline & & & & & $\begin{array}{l}\text { Gren \& Recycled Construction } \\
\text { materials,energy efficient } \\
\text { machineries, low Carbon }\end{array}$ & Designer \\
\hline & & \multirow[t]{2}{*}{$\begin{array}{l}\text { Buggy Track } \\
\text { Workshop }\end{array}$} & Shopping Area & & $\begin{array}{l}\text { Gren \& Recycled Construction } \\
\text { materials,energy efficient } \\
\text { machineries, low Carbon }\end{array}$ & Designer \\
\hline & & & Charging & & Energy Efficient system & Designer \\
\hline & & \multirow{2}{*}{$\begin{array}{l}\text { Workshop } \\
\text { Buggy Cars }\end{array}$} & Maint. \& Repair Centre & & $\begin{array}{l}\text { Energy Efficient system, Green } \\
\text { waste Management }\end{array}$ & Designer,Operator \\
\hline & & & General Purpose Buggy & Passenger Buggy & Energy Saving System & Operator \\
\hline & & \multirow[t]{2}{*}{ Buggy Cars } & Special Purpose Buggy & VVIP buggy & Energy Saving System & Operator \\
\hline & & & Special Purpose Buggy & Emergency & Energy Saving System & Operator \\
\hline
\end{tabular}

TABLE 3 .

SUSTAINABILITY ELEMENTS FOR SEA CRAFT AND JETTY SYSTEMS

\begin{tabular}{|c|c|c|c|c|c|}
\hline Category & System & sub-system & sub-sub-sub system & Sustainability Element (Eg) & Party in Charge \\
\hline \multirow{9}{*}{$\begin{array}{l}\text { Sea } \\
\text { Transport }\end{array}$} & \multirow{6}{*}{$\begin{array}{l}\text { Sea } \\
\text { Crafts }\end{array}$} & Water Taxi & & $\begin{array}{l}\text { Green design,Energy Efficient } \\
\text { System, Low Carbon Emission, } \\
\text { Low Wake Wash }\end{array}$ & Designer, Operator \\
\hline & & \multirow{3}{*}{ TPEP Crafts } & Patrol Boat & $\begin{array}{l}\text { Green design,Energy Efficient } \\
\text { System, Low Carbon Emission, } \\
\text { Low Wake Wash }\end{array}$ & Designer, Operator \\
\hline & & & Service Boat & $\begin{array}{l}\text { Green design,Energy Efficient } \\
\text { System, Low Carbon Emission, } \\
\text { Low Wake Wash }\end{array}$ & Designer, Operator \\
\hline & & & Emergency Boat & $\begin{array}{l}\text { Green design,Energy Efficient } \\
\text { System, Low Carbon Emission, } \\
\text { Low Wake Wash }\end{array}$ & Designer, Operator \\
\hline & & \multirow{2}{*}{ Other Crafts } & Commercial Crafts & $\begin{array}{l}\text { Green design,Energy Efficient } \\
\text { System, Low Carbon Emission, } \\
\text { Low Wake Wash }\end{array}$ & Designer, Operator \\
\hline & & & Visitors Craft & $\begin{array}{l}\text { Green design,Energy Efficient } \\
\text { System, Low Carbon Emission, } \\
\text { Low Wake Wash }\end{array}$ & Designer, Operator \\
\hline & \multirow{3}{*}{ Jetties } & Jetty & & $\begin{array}{l}\text { Green \& Recycled construction } \\
\text { materials, Energy Efficient } \\
\text { machineries, Low carbin } \\
\text { emission machineries }\end{array}$ & Designer \\
\hline & & $\begin{array}{l}\text { Cargo } \\
\text { Facilities }\end{array}$ & & $\begin{array}{l}\text { Energy Efficient system, } \\
\text { efficient energy usage }\end{array}$ & Designer, Operator \\
\hline & & $\begin{array}{l}\text { Passenger } \\
\text { Facilities }\end{array}$ & & $\begin{array}{l}\text { Energy Efficient system, } \\
\text { efficient energy usage }\end{array}$ & Designer, Operator \\
\hline
\end{tabular}




\section{DISCUSSION AND CLOSING}

Principal strength of the proposed model and checklists are worth highlighting. Firstly, sustainability of transportation system is something that is well planned and traceable to the efforts put in laying out the development plan to be used for project tendering. Sustainability of a system is contributed by two aspects; the design of the system itself and the way the system is operated. Hence a sustainability checklist must be prepared with an aim of identifying sustainability elements that designers are responsible of and sustainability elements that operators are responsible of. Is shall not be limited to statements that record commitment of developers for too big a sustainability headings such as management of waste during construction period or guarantee in providing alternatives for low energy transportation system. Too vague a checklist in term of who will shoulder the final responsibility of carrying it out will render it useless especially for close and effective project control purposes.

Secondly, an elemental transportation system model developed with a consistence approach in identifying the smallest physical element required by a mangrove ecopark is critical in developing transportation system sustainability checklist. The party responsible in carrying out the duty can then be identified with confident. Designers will shoulder the task of embedding sustainability qualities in their systems' design encompassing the use of recycled and/or environmentally friendly materials, energy-efficient construction methods and sustainable waste management during construction period. Operators taking over the site will shoulder the tasks of procuring equipment with sustainability-oriented technical specifications such as low energy usage system equipped with performance monitoring system, low noise so as to be friendly with the local habitat and promote green and sustainable operation. Subdividing physical items into logical groupings is advantageous since huge system may have to be operated by many different groups of operators. Sub and sub-sub systems of the whole transportation system will have been developed coherently. The anchor operator will coordinate running of the system to achieve the sustainability targets.

Thirdly, all sustainability elements recorded in the checklist can be clearly spelled in contract documents binding mangrove eco-park owner with the developer and in contract documents binding the eco-park owners with the different operators. For the earlier, contract clauses can be easily drafted so that sustainability targets are set as specifications describing the works to be delivered by the contractors. it has to be consistence throughout the contract; specifying it in the preamble, the general contractual clauses, the description of works, the technical specifications as well as the terms of payment. Appropriate values should be attached to the delivery of each sustainability quality of the works to be delivered so that contractors are aware of the financial repercussion of not delivering it. Project engineers can monitor the process of delivering the works with sufficient focus given on to ensure sustainability qualities are indeed complied with. Project managers could confidently pursue cases of non-delivery of sustainability quality since that the contract clauses relevant to the cases have been clearly stated. Close and effective monitoring of the delivery of the project; construction and operating of transportation system, are therefore possible with sustainability checklist proposed taken as the basis of constructing the project documents.

Fourthly, based on the checklist standard operating procedures can be developed for the running of the transportation system. Technical specifications that have been designed in line with sustainability requirement appearing in the checklist will be useful in constructing the detailed maintenance and operation manual for each of the physical system. Operating procedures inclined towards preserving the environment as a whole thus giving benefits to the three pillars of sustainability vis-àvis environment, economic and society will set recommended operating values and/or limits not to be surpassed during operation. Engineers entrusted with developing the maintenance and operation manual will be able to easily capture sustainability qualities earlier specified in the project checklist while adding to it or updating it with recent specifications obtained elsewhere. Likewise, templates attached to the maintenance and operation manual such as maintenance and repair records mandatory for operators to fill up and later surrender to the mangrove eco-park owner at every end of scheduled maintenance period can easily be produced. Engineers attending and overseeing the operation and maintenance of the system will have a solid document to refer to throughout the contract period thus making the whole effort of managing it much easier.

As a closing remark the sustainability checklist developed for the Tanjong Pelepas Mangrove Eco-Park development project can be claimed as a tool with extended use. The tool that has been developed based on an elemental model identifying the many physical system of the transportation system. The tool is later used to prepare the tender documents for the physical construction phase and manuals for project engineers and managers during the phase. The tool can be expended to include detailed sustainability-oriented system's technical specifications and as such making it as immediate reference to operators when attached in the operation and maintenance manual for the operational phase.

\section{ACKNOWLDEGMENT}

The study has been fully funded by Institut Sultan Iskandar (ISI) of Universiti Teknologi Malaysia. The authors acknowledge the great contribution by ISI.

\section{REFERENCES}

Books:

[1] Webber, M. Calumpong, H. Ferreira, B. Granek, E. Green, S Ruwa, R. Soares, M., Chapter 48. Mangroves, http://www.un.org/depts/los/global_reporting/WOA_RPROC/Cha pter_48.pdf, 2017, 24 August $201 \overline{7}$. 
[2] Woodroffe, C., Robertson, A. and Alongi, D. Mangrove sediments and geomorphology. In: Robertson, A.I. and Alongi, D.M. (eds.). Tropical mangrove ecosystems. American Geophysical Union, Washington, D.C., 1992.

[3] Yao, C. E., Existing and Potential Ecotuorism Mangrove Destinations

Bohol,http://oneocean.org/download/db_files/NotesOnBoholMang roveEcotourismDestinations.pdf, 30 August 2017

[4] MohdZamani, A., Ahmad, M.H. and NurHanani, A.Z., Liveability and Sustainability Based Framework and Process Models for Engineering System Design, Narotama International Conference on Civil Engineering 2015 (NICCE-2015), Indonesia,2015.

[5] Welwyn Hatfield District Plan, Welwyn Hatfield District Plan, http://www.welhat.gov.uk/CHttpHandler.ashx?id=933\&p=0, October, 2017.

[6] Lewes District Council,LEWES DISTRICT COUNCIL SUSTAINABILITY CHECKLIST, http://www.lewes.gov.uk/Files/plan_sustainability_checklist(1).pdf , November, 2017.

[7] Dorset District Council, Development Framework, Sustainability checklist, Dorset Strategic Partnership, https://www.dorsetforyou.gov.uk/media/116462/3.-SustainabilityChecklist/pdf/3.pdf, October, 2017.

\section{Periodicals:}

[3] J. U. Duncombe, "Infrared navigation-Part I: An assessment of feasibility,” IEEE Trans. Electron Devices, vol.ED-11, pp. 34-39, Jan. 1959.

[4] E. P. Wigner, "Theory of traveling-wave optical laser,"Phys. Rev., vol. 134, pp. A635-A646, Dec. 1965.

Papers Presented at Conferences (unpublished):

[5] D. Ebehard and E. Voges, "Digital single sideband detection for interferometric sensors," presented at the 2nd Int.Conf. Optical Fiber Sensors, Stuttgart, Germany, 1984.

\section{Standards/Patents:}

[6] G. Brandli and M. Dick, "Alternating current fed power supply," U.S. Patent 4084 217, Nov. 4, 1978. 